\title{
Mycophenolate-induced Colitis: A Case Report with Focused Review of Literature
}

\author{
Rehan Farooqi $^{1}$, Afrin Kamal ${ }^{2}$, Carol Burke ${ }^{2}$ \\ 1. Internal Medicine, Medstar Union Memorial Hospital, Baltimore, USA 2. Gastroenterology, Cleveland Clinic, \\ Cleveland, USA
}

Corresponding author: Rehan Farooqi, rehan.m.farooqi@medstar.net

\begin{abstract}
Mycophenolate mofetil (MMF) is an immunosuppressive medication used for the management of various autoimmune diseases, and patients with bone marrow and solid organ transplants. Gastrointestinal side effects are seen $45 \%$ of the time and they include nausea (29\%), vomiting (23\%), constipation (38\%), diarrhea (50\%-92\%), and colitis (9\%). In 98\% of cases, resolution of diarrhea occurs within 20 days upon discontinuation of the MMF. Data is scarce regarding approach in the treatment of MMF-induced colitis. We report a case of MMF-induced colitis diagnosed by colonoscopy and histopathology. This case illustrates the challenges encountered while managing MMF-induced colitis.
\end{abstract}

Categories: Internal Medicine, Pathology, Gastroenterology

Keywords: colitis, mycophenolate induced colitis, crypt cell apoptosis, drug induced colitis, ulcerative colitis, inflammatory bowel disease (ibd)

\section{Introduction}

Mycophenolate mofetil (MMF) is an immunosuppressive medication commonly used to prevent rejection in solid organ transplant recipients. Active metabolite of MMF, mycophenolic acid, inhibits inosine monophosphate dehydrogenase which is the rate-limiting enzyme in purine synthesis for T and B-cell proliferation [1]. Enterocytes are 50\% dependent on the de novo pathway of purine synthesis which is why they are vulnerable to MMF's antimetabolic effects; this impedes the growth and replication of small bowel epithelial cells which leads to disruption of fluid absorption and diarrhea [2]. Injurious effects of MMF can be detected in the colon and include mucosal changes ranging from edema, erythema, erosions, and ulcerations. Histopathologic findings of MMF injury include crypt architectural distortion and crypt cell apoptosis [2]. The latency period between initiation of MMF exposure and onset of enterocolitis is between six months to 15 years with the average being around three years [3].

Received 01/14/2020 Review began 01/17/2020 Review ended 01/20/2020 Published 01/25/2020

\section{(c) Copyright 2020}

Faroogi et al. This is an open access article distributed under the terms of the Creative Commons Attribution License CC-BY 3.0., which permits unrestricted use, distribution, and reproduction in any medium, provided the original author and source are credited.

\section{Case Presentation}

A 68-year-old male with a history of recurrent deep vein thrombosis on warfarin, single lung transplant secondary to idiopathic pulmonary fibrosis on MMF (1000 mg twice a day) for eight months prior to admission, diverticulitis and recurrent diverticular bleed complicated by sigmoidectomy and right colectomy with ileo-colonic anastomosis, respectively, presented with 6-8 episodes of maroon-colored stools daily for the past two months. Over this time, the patient had several admissions at different hospitals requiring blood transfusions and endoscopic evaluations. At an outside hospital,

esophagogastroduodenoscopy (EGD) demonstrated esophageal, gastric, and duodenal ulcers. He was treated with oral mesalamine for presumed inflammatory bowel disease. The patient was referred to the hospital for a second opinion after his symptoms did not improve.

Physical examination was significant for a chronically ill-appearing man with mild tenderness in the right lower quadrant of the abdomen and maroon colored stools on digital rectal exam. The rest of the examination was unremarkable. Laboratory studies revealed a hemoglobin level of $9.4 \mathrm{~g} / \mathrm{dL}$ (normal range, 13.5-17.5 g/dL), iron $36 \mathrm{ug} / \mathrm{dL}$ (normal range, 41-186 ug/dL), ferritin $134.5 \mathrm{ng} / \mathrm{mL}$ (normal range, 30 - 565 $\mathrm{ng} / \mathrm{mL}$ ), and creatinine of $1.64 \mathrm{mg} / \mathrm{dL}$ (normal range, $0.73-1.22 \mathrm{mg} / \mathrm{dL}$ ). Electrolytes, liver function, blood cytomegalovirus DNA, stool for ova \& parasites, interferon-gamma release assay, and stool Clostridium difficile antigen were negative. A magnetic resonance enterography (MRE) of the abdomen and pelvis demonstrated small bowel wall thickening, mural hyper-enhancement, and peri-enteric stranding involving a 10-cm segment of the distal terminal ileum extending to the ileo-colonic anastomosis (Figure 1). 


\section{Cureus}

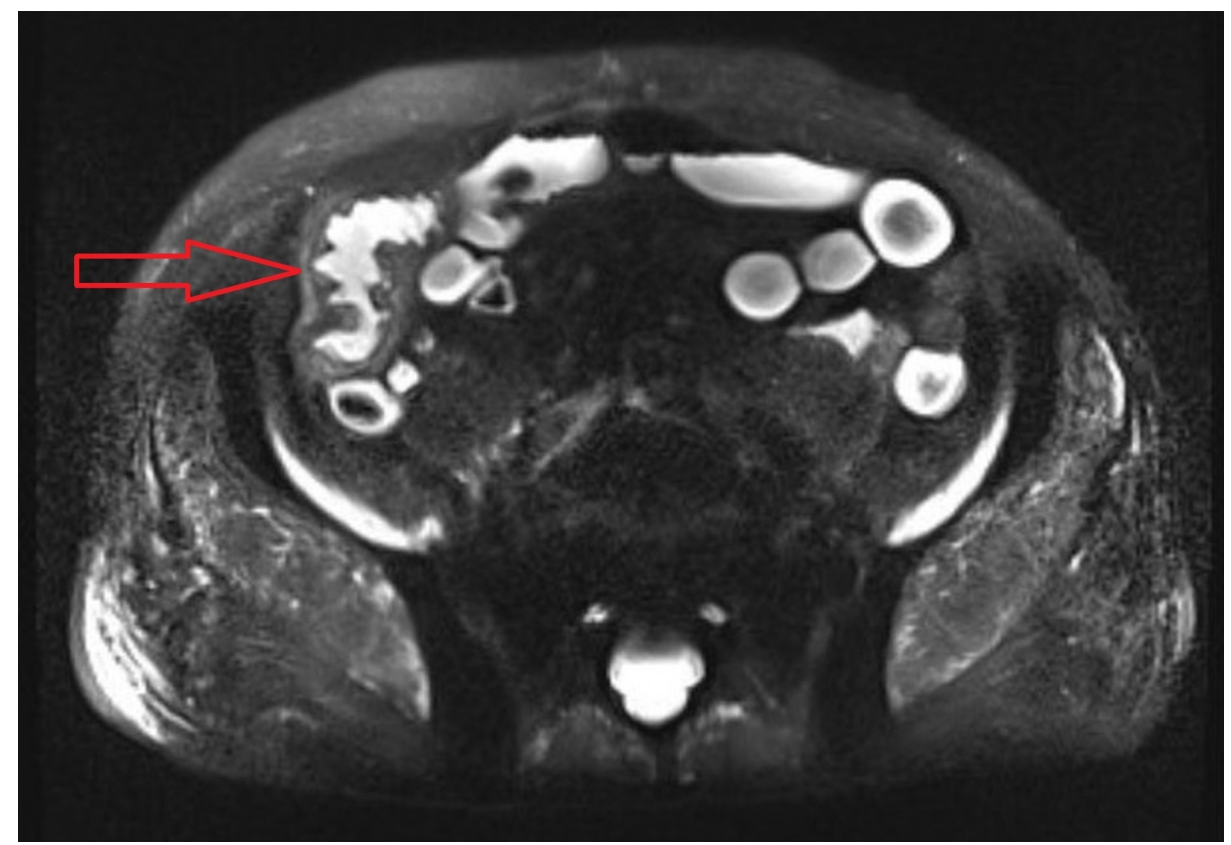

FIGURE 1: Magnetic resonance enterography depicting small bowel wall thickening, mural hyper enhancement and peri-enteric stranding involving $10-\mathrm{cm}$ segment of the distal terminal ileum (red arrow)

No active inflammation in the colon or rectum was noted. An EGD demonstrated a normal esophagus, stomach, and duodenum. Colonoscopy revealed numerous ulcers in the ascending colon, ileo-colonic anastomosis, and in the distal $15-\mathrm{cm}$ of the neo-terminal ileum with normal-appearing intervening mucosa (Figure 2).
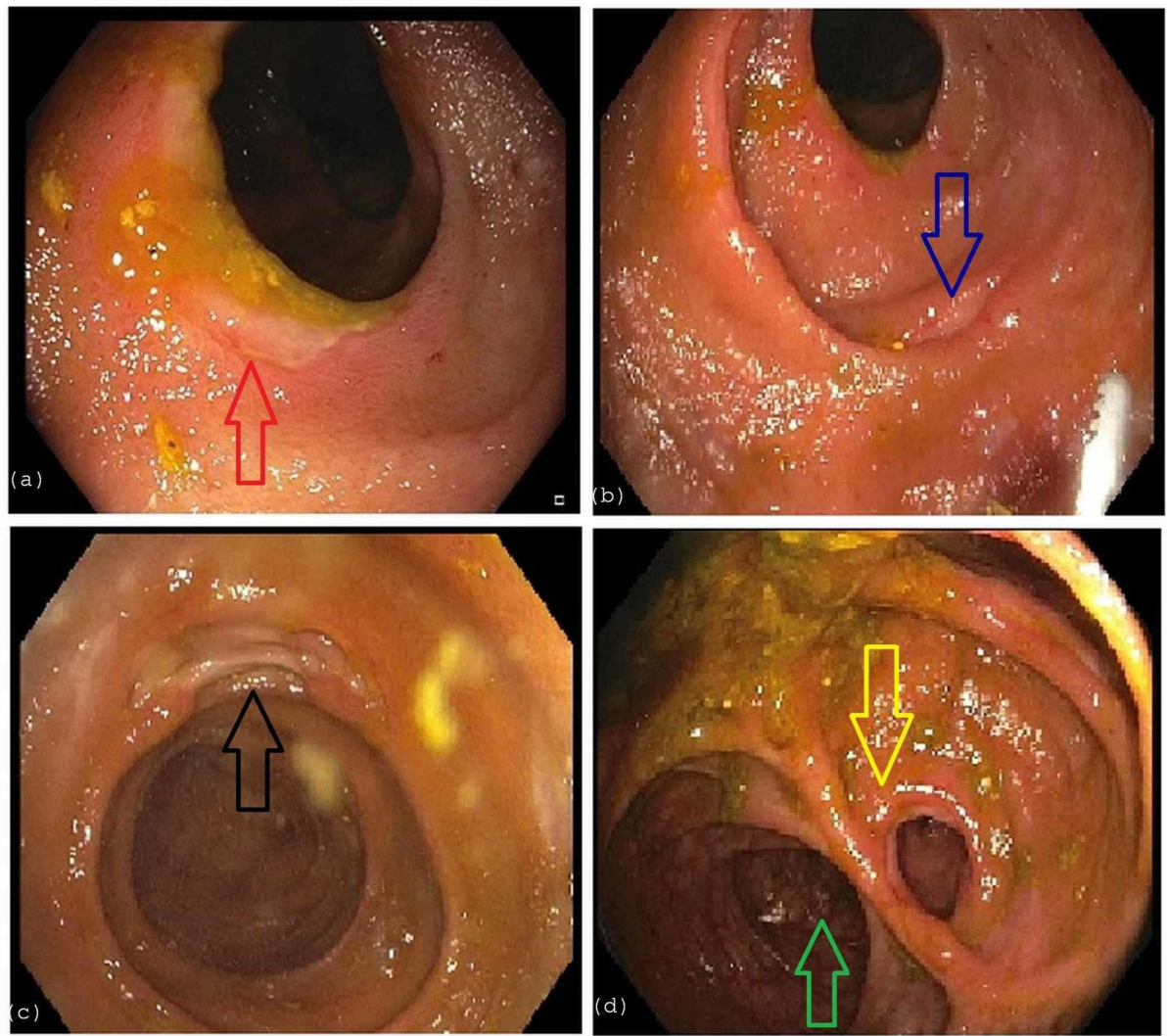

FIGURE 2: Colonoscopy 


\section{Cureus}

a) depicts ulceration (red arrow) in the ascending colon. b,c) depict ulceration in the distal $15 \mathrm{~cm}$ of the neoterminal ileum (blue and black arrows) with normal-appearing intervening mucosa. d) visualizes anastomosis of the distal ileum (yellow arrow) to the transverse colon (green arrow).

Biopsy of the ulcers with immunohistochemical staining for cytomegalovirus was negative. Histology revealed mild crypt architectural distortion with crypt cell apoptosis from the ascending colonic ulcers and patchy active ileitis from the ileo-colonic anastamotic ulcerations (Figure 3).

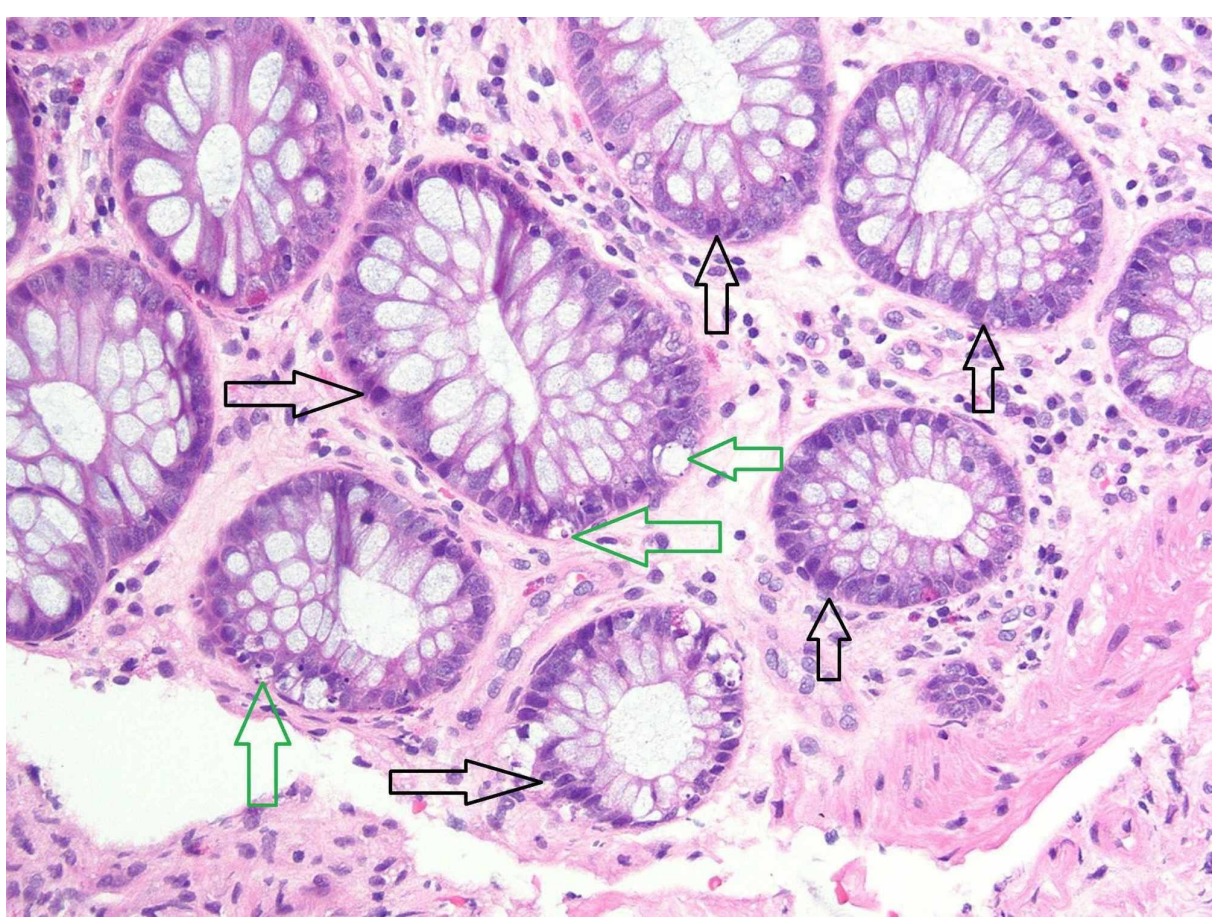

FIGURE 3: Photomicrograph from the colon biopsy showing architectural distortion with unevenly spaced lumen and crypts

Several damaged crypts (black arrows) are present, scattered throughout the colonic mucosa (hematoxylin and eosin (H\&E), original magnification x100). Also present are apoptotic bodies (green arrows) suggestive of cellular injury and turnover (H\&E, original magnification $\times 100)$. There is no evidence of active inflammation or viral cytopathic effect.

In view of MMF exposure and histopathologic findings of crypt architectural distortion and crypt cell apoptosis, our patient was diagnosed with MMF-induced enterocolitis and MMF was promptly discontinued.

Seventy-two hours after discontinuation of MMF, the patient continued to experience bloody diarrhea requiring RBC transfusions. Intravenous (IV) Solumedrol $20 \mathrm{mg}$ every eight hours was initiated with mild improvement in the frequency of diarrhea. After five days of IV Solumedrol therapy, a repeat colonoscopy demonstrated evidence of complete healing of the numerous small ulcerations and improvement in the appearance of the large ulcerations, suggestive of overall endoscopic improvement (Figure 4).
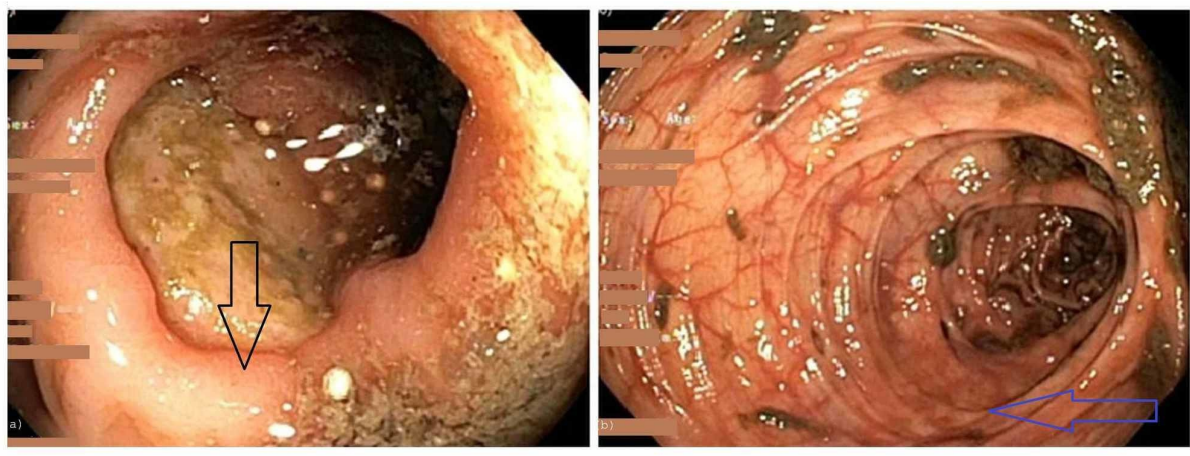

FIGURE 4: Repeat colonoscopy after five days of intravenous steroids 
The patient was transitioned to oral steroids and steadily experienced clinical improvement. Unfortunately, the patient's hospital stay was complicated by hypoxic respiratory failure and he succumbed to death from aspiration pneumonia.

\section{Discussion}

MMF is a commonly prescribed adjunct immunosuppressive agent in transplant therapy. Up to $45 \%$ of patients report diarrhea, vomiting, and abdominal pain; diarrhea being the most commonly reported side effect $[4,5]$. As an immunosuppressant, MMF can affect the entire gastrointestinal system leading to clinical complications ranging from esophagitis, gastroesophageal reflux disease, to enteritis and colitis. Development of diarrhea due to enteritis and/or colitis can be difficult to recognize as only $2 \%-9 \%$ of patients on MMF develop these complications [5,6]. Pathology can resemble inflammatory bowel disease, graft-versus-host disease (GVHD), acute colitis or ischemia [6]. There are treatment differences for each condition which is why obtaining biopsies is recommended to differentiate between these etiologies [7]. Specific histologic features of MMF related colitis include: crypt architectural disarray, increased lamina propria inflammation, dilated damaged crypts, increased crypt epithelial apoptosis and GVHD-like changes [8].

No guidelines are available to guide clinicians to treat MMF-induced enterocolitis. Several case reports have demonstrated that diarrhea improves within three to five days of discontinuing MMF [9-10]. One systemic review revealed that in $98 \%$ of the cases, diarrhea resolves within 20 days upon discontinuation of the MMF [3]. If symptoms are persistent despite MMF discontinuation, prednisone and/or infliximab has shown improvement.

Table 1 lists the cases of MMF induced colitis and how these patients were managed [10-19]. In 12 of the 13 case reports found, patient's symptoms improved after lowering the offending agent dose or discontinuing the medication. Out of the 13 , only two patients were already on steroids [13,14]. Out of the 13 cases, six of them underwent repeat colonoscopy at different times from the intervention to assess for healing [14-

19]. Bouhbouh et al. gave a single infusion of $5 \mathrm{mg} / \mathrm{kg}$ of infliximab after previous futile attempts with MMF discontinuation, and $50 \mathrm{mg}$ of prednisolone IV daily for two weeks [11]. Within three days, after a single infusion of infliximab, the stool frequency dropped significantly [11].

\begin{tabular}{|c|c|c|c|c|c|c|c|}
\hline & $\begin{array}{l}\text { Mycophenolate } \\
\text { mofetil (MMF) } \\
\text { dosing }\end{array}$ & $\begin{array}{l}\text { Main } \\
\text { symptom }\end{array}$ & Endoscopic findings & Histologic findings & $\begin{array}{l}\text { Steroids } \\
\text { given? } \\
\text { (dosing) }\end{array}$ & $\begin{array}{l}\text { Infliximab } \\
\text { Given? } \\
\text { (dosing) }\end{array}$ & $\begin{array}{l}\text { Timing of symptom } \\
\text { improvement }\end{array}$ \\
\hline $\begin{array}{l}\text { Bouhbouh } \\
\text { (2010) }\end{array}$ & $500 \mathrm{mg}$ BID & $\begin{array}{l}\text { Watery, non- } \\
\text { bloody } \\
\text { diarrhea, } \\
\text { abdominal } \\
\text { pain, weight } \\
\text { loss }\end{array}$ & $\begin{array}{l}\text { Linear ulcerations throughout } \\
\text { colon }\end{array}$ & $\begin{array}{l}\text { Extensive ulceration with transmural } \\
\text { mixed-cellular infiltration without } \\
\text { granulomata }\end{array}$ & $\begin{array}{l}\text { Yes. } 2 \\
\text { weeks of } \\
\text { Prednisone } \\
30 \mathrm{mg} \text { PO } \\
\text { daily, } \\
\text { followed by } \\
2 \text { weeks of } \\
25 \mathrm{mg} \\
\text { prednisolone } \\
\text { IV BID }\end{array}$ & $\begin{array}{l}\text { Yes } \\
(5 \mathrm{mg} / \mathrm{kg})\end{array}$ & $\begin{array}{l}72 \text { hours after } \\
\text { Infliximab }\end{array}$ \\
\hline $\begin{array}{l}\text { Johal } \\
\text { (2014) }\end{array}$ & $1,500 \mathrm{mg}$ BID & $\begin{array}{l}\text { Watery, non- } \\
\text { bloody } \\
\text { diarrhea, } \\
\text { abdominal } \\
\text { pain, weight } \\
\text { loss }\end{array}$ & $\begin{array}{l}\text { Segmental erythematous mucosa } \\
\text { with ulcers in sigmoid, } \\
\text { descending, splenic flexure and } \\
\text { proximal transverse colon }\end{array}$ & $\begin{array}{l}\text { Dilated crypts, eosinophilic epithelial } \\
\text { changes, crypt abscesses with } \\
\text { apoptotic bodies }\end{array}$ & No & No & $\begin{array}{l}5 \text { weeks following } \\
\text { MMF cessation }\end{array}$ \\
\hline $\begin{array}{l}\text { Goyal } \\
\text { (2016) }\end{array}$ & Not provided & $\begin{array}{l}\text { Watery, non- } \\
\text { bloody } \\
\text { diarrhea, } \\
\text { abdominal } \\
\text { tenderness } \\
\text { and } \\
\text { distention }\end{array}$ & Normal mucosa & $\begin{array}{l}\text { Crypt atrophy, increased crypt } \\
\text { apoptosis }\end{array}$ & No & No & $\begin{array}{l}3 \text { days following } \\
\text { MMF cessation }\end{array}$ \\
\hline
\end{tabular}




\section{Cureus}

\begin{tabular}{|c|c|c|c|c|c|c|c|}
\hline $\begin{array}{l}\text { Jakes } \\
\text { (2012) }\end{array}$ & $750 \mathrm{mg}$ bid & $\begin{array}{l}\text { Abdominal } \\
\text { pain and } \\
\text { weight loss }\end{array}$ & $\begin{array}{l}\text { Patchy inflammation of } \\
\text { ascending colon, ileocecal valve } \\
\text { was grossly thickened, stenosed, } \\
\text { and ulcerated, consistent with a } \\
\text { Crohn's-like disease process. }\end{array}$ & Extensive ulceration & No & No & $\begin{array}{l}8 \text { weeks following } \\
\text { MMF reduction first } \\
\text { to } 250 \mathrm{mg} \text { bid and } \\
\text { eventually } \\
\text { discontinuing. Pt } \\
\text { also underwent ex- } \\
\text { lap s/p right } \\
\text { hemicolectomy with } \\
\text { no evidence of } \\
\text { inflammatory } \\
\text { changes within } \\
\text { small or large bowel }\end{array}$ \\
\hline $\begin{array}{l}\text { Jakes } \\
\text { (2012) }\end{array}$ & $750 \mathrm{mg}$ bid & $\begin{array}{l}\text { Watery, non } \\
\text { bloody } \\
\text { diarrhea with } \\
\text { large mucus }\end{array}$ & Severe pancolitis & $\begin{array}{l}\text { Noncaseating granulomas within the } \\
\text { lamina propria consistent with Crohns } \\
\text { Disease }\end{array}$ & No & No & $\begin{array}{l}\text { Resolution of colitis } \\
\text { after MMF } \\
\text { cessation, duration } \\
\text { unknown }\end{array}$ \\
\hline $\begin{array}{l}\text { Jakes } \\
\text { (2012) }\end{array}$ & $180 \mathrm{mg}$ bid & $\begin{array}{l}\text { Profuse } \\
\text { watery, non } \\
\text { bloody } \\
\text { diarrhea with } \\
\text { right lower } \\
\text { quadrant } \\
\text { abdominal } \\
\text { tenderness }\end{array}$ & Pancolitis with rectal sparing & Focal active colitis, no granulomas. & No & No & $\begin{array}{l}8 \text { months after } \\
\text { discontinuation of } \\
\text { Myfortic, patient } \\
\text { had sigmoidoscopy } \\
\text { which showed no } \\
\text { active } \\
\text { inflammation. } \\
\text { Unknown when } \\
\text { patient noted } \\
\text { improvement in } \\
\text { symptoms }\end{array}$ \\
\hline $\begin{array}{l}\text { Moroncini } \\
\text { (2018) }\end{array}$ & $\begin{array}{l}\text { Not provided } \\
\text { but started } 2 \\
\text { months ago }\end{array}$ & $\begin{array}{l}\text { Left sided } \\
\text { abdominal } \\
\text { pain, } \\
\text { nausea, } \\
\text { vomiting, } \\
\text { and fever }\end{array}$ & $\begin{array}{l}\text { Mucosal hyperemia, multiple } \\
\text { serpiginous ulcers involving the } \\
\text { transverse and descending } \\
\text { colonic mucosa, with rectal } \\
\text { sparing }\end{array}$ & $\begin{array}{l}\text { ulceration, granulation tissue and } \\
\text { hyalinised appearance of the mucosa } \\
\text { and submucosa }\end{array}$ & No & No & $\begin{array}{l}5 \text { days following } \\
\text { MMF } \\
\text { discontinuation. } \\
\text { Repeat } \\
\text { colonoscopy } 1 \\
\text { month later showed } \\
\text { complete resolution } \\
\text { of ulcer }\end{array}$ \\
\hline $\begin{array}{l}\text { Tayyem } \\
\text { (2018) }\end{array}$ & $\begin{array}{l}500 \mathrm{mg} \text { bid and } \\
\text { Prednisone } 15 \\
\text { mg daily }\end{array}$ & $\begin{array}{l}\text { non-bloody } \\
\text { diarrhea, } \\
\text { dysphagia to } \\
\text { solid food, } \\
\text { nausea and } \\
\text { unintentional } \\
\text { weight loss } \\
\text { of } 2 \text { weeks' } \\
\text { duration. }\end{array}$ & $\begin{array}{l}\text { EGD: normal oesophagus, } \\
\text { multiple small antral ulcers and } \\
\text { reactive gastropathy. } \\
\text { Colonoscopy: mucosal edema } \\
\text { and erythema with small mucosal } \\
\text { hemorrhages and punctate } \\
\text { ulcerations in the ascending } \\
\text { colon, patchy colitis in the } \\
\text { transverse colon and rectal } \\
\text { sparing }\end{array}$ & $\begin{array}{l}\text { Colonic biopsies showed focal crypt } \\
\text { abscesses (withered crypts) with } \\
\text { occasional apoptosis of epithelial cells, } \\
\text { frequent tingible body macrophages and } \\
\text { eosinophils within the lamina propria }\end{array}$ & $\begin{array}{l}\text { Patient was } \\
\text { already on } \\
\text { Prednisone } \\
15 \text { mg daily }\end{array}$ & No & $\begin{array}{l}5 \text { weeks after MMF } \\
\text { discontinuation }\end{array}$ \\
\hline $\begin{array}{l}\text { Gorospe } \\
\text { (2012) }\end{array}$ & $1000 \mathrm{mg}$ bid & $\begin{array}{l}\text { 2-week } \\
\text { history of } \\
\text { profuse, } \\
\text { watery } \\
\text { diarrhoea } \\
\text { that } \\
\text { persisted } \\
\text { through the } \\
\text { night and } \\
\text { with fasting }\end{array}$ & $\begin{array}{l}\text { Flexible sigmoidoscopy showed } \\
\text { mild erythema }\end{array}$ & $\begin{array}{l}\text { apoptosis, crypt distortion and abscess; } \\
\text { consistent with MMF-induced colitis }\end{array}$ & No & No & $\begin{array}{l}\text { Five days later, the } \\
\text { patient's stool } \\
\text { frequency } \\
\text { decreased to twice } \\
\text { daily until complete } \\
\text { resolution. At } 1 \\
\text { month follow-up, } \\
\text { her MMF was } \\
\text { restarted at a lower } \\
\text { dose (500 mg/day) } \\
\text { which was tolerated } \\
\text { well without any } \\
\text { recurrence of } \\
\text { gastrointestinal } \\
\text { issues. }\end{array}$ \\
\hline & & & & mild crypt architectural distortion (Figure & & & $\begin{array}{l}\text { Symptoms } \\
\text { regressed within } 5\end{array}$ \\
\hline
\end{tabular}




\section{Cureus}

\begin{tabular}{|c|c|c|c|c|c|c|c|}
\hline $\begin{array}{l}\text { Hamouda } \\
\text { (2012) }\end{array}$ & $\begin{array}{l}\text { Prednisone and } \\
\text { MMF. Dosages } \\
\text { not known }\end{array}$ & $\begin{array}{l}\text { Profuse } \\
\text { watery } \\
\text { diarrhea, } 6 \\
\text { to } 8 \text { times } \\
\text { per day and } \\
\text { weight loss }\end{array}$ & $\begin{array}{l}\text { ulcerative diffuse colitis from the } \\
\text { cecum to the rectum }\end{array}$ & $\begin{array}{l}\text { 1). The lamina propria showed edema } \\
\text { and an increased number of } \\
\text { inflammatory cells containing many } \\
\text { neutrophils. Damaged crypts with } \\
\text { mucus depletion and cryptitis. No } \\
\text { granuloma }\end{array}$ & No & No & $\begin{array}{l}\text { days after switching } \\
\text { from MMF to } \\
\text { azathioprine. } \\
\text { Control } \\
\text { colonoscopy } \\
\text { showed reparative } \\
\text { changes after } 2 \\
\text { months }\end{array}$ \\
\hline $\begin{array}{l}\text { Kim } \\
(2000)\end{array}$ & $\begin{array}{l}\text { Dose not } \\
\text { known but } \\
\text { between } 2 \text { to } 3 \\
\text { gm daily. }\end{array}$ & $\begin{array}{l}\text { abdominal } \\
\text { pain and } \\
\text { watery } \\
\text { diarrhea } \\
\text { which } \\
\text { progressed } \\
\text { to bloody } \\
\text { diarrhea }\end{array}$ & $\begin{array}{l}\text { multiple ulcers and mucosal } \\
\text { hyperemia and edema in the } \\
\text { entire colon }\end{array}$ & $\begin{array}{l}\text { Histology did not reveal viral cytopathic } \\
\text { changes and immunohistochemical } \\
\text { stains for cytomegalovirus infection } \\
\text { were negative. }\end{array}$ & $\begin{array}{l}\text { Patient was } \\
\text { already on } \\
\text { steroids }\end{array}$ & No & $\begin{array}{l}\text { Abdominal pain and } \\
\text { hematochezia } \\
\text { improved rapidly. } \\
\text { Follow-up } \\
\text { colonoscopy } 1 \\
\text { month later showed } \\
\text { complete healing of } \\
\text { previous lesions }\end{array}$ \\
\hline $\begin{array}{l}\text { Johal } \\
\text { (2014) }\end{array}$ & $\begin{array}{l}1000 \mathrm{mg} \text { bid } \\
\text { and increased } \\
\text { to } 1500 \mathrm{mg} \text { bid } \\
\text { four months } \\
\text { prior to } \\
\text { presentation }\end{array}$ & $\begin{array}{l}\text { Abdominal } \\
\text { pain, } \\
\text { nausea, } \\
\text { intermittent } \\
\text { bloating and } \\
\text { profuse } \\
\text { watery non } \\
\text { bloody } \\
\text { diarrhea. }\end{array}$ & $\begin{array}{l}\text { segmental erythematous mucosa } \\
\text { and multiple ulcers in the } \\
\text { sigmoid colon, descending } \\
\text { colon, splenic flexure and } \\
\text { proximal transverse colon }\end{array}$ & $\begin{array}{l}\text { dilated damaged crypts, eosinophilic } \\
\text { epithelial changes and crypt abscesses } \\
\text { with apoptotic bodies, a pattern of injury } \\
\text { highly suggestive of MMF-related colitis }\end{array}$ & No & No & $\begin{array}{l}5 \text { weeks after MMF } \\
\text { discontinuation }\end{array}$ \\
\hline $\begin{array}{l}\text { Sonoda } \\
(2017)\end{array}$ & 1gm daily & $\begin{array}{l}\text { Watery } \\
\text { diarrhea } \\
\text { which } \\
\text { progressed } \\
\text { to bloody } \\
\text { diarrhea }\end{array}$ & multiple deep ulcers in the ileum & mild crypt distortion & No & No & $\begin{array}{l}\text { Symptoms } \\
\text { improved soon after } \\
\text { MMF was } \\
\text { discontinued. Six } \\
\text { months later, the } \\
\text { ileal mucosa was } \\
\text { healed }\end{array}$ \\
\hline $\begin{array}{l}\text { (Patra) } \\
2012\end{array}$ & Not provided & $\begin{array}{l}\text { Significant } \\
\text { weight loss, } \\
\text { sitophobia } \\
\text { for five } \\
\text { months, and } \\
\text { a recent } \\
\text { onset of } \\
\text { bleeding per } \\
\text { rectum }\end{array}$ & $\begin{array}{l}\text { Colonoscopy demonstrated ileal } \\
\text { and cecal ulcers }\end{array}$ & $\begin{array}{l}\text { Histopathology revealed crypt dropout, } \\
\text { with focal disarray of the crypt } \\
\text { architecture, along with apoptosis of the } \\
\text { crypt epithelial cells. The crypt epithelial } \\
\text { apoptotic rate was greater than } 5 \text { / } 100 \\
\text { crypts. The lamina propria was } \\
\text { edematous and showed focal collection } \\
\text { of mild lymphomononuclear } \\
\text { inflammatory cell infiltrate }\end{array}$ & $\begin{array}{l}\text { Patient } \\
\text { already on } \\
\text { steroids, } \\
\text { unknown } \\
\text { dose }\end{array}$ & No & $\begin{array}{l}1 \text { week after MMF } \\
\text { cessation. Repeat } \\
\text { colonoscopy after } 1 \\
\text { month showed } \\
\text { healing ulcers }\end{array}$ \\
\hline
\end{tabular}

TABLE 1: Illustrates reported cases of mycophenolate-induced colitis to date with different management strategies that have been used; the table also indicates the timing of symptom improvement from the intervention

Important to note that all patients underwent colonoscopy and/or flexible sigmoidoscopy for tissue pathology.

The mucosal injury from MMF is thought to be related to the formation of immunotoxicologic reactions in the bowel, increased mucosal inflammation, and decreased mucosal protection [20]. The decreased mucosal protection is hypothesized secondary to the upregulation of intracellular phosphatidylcholines, prominent membrane phospholipid that maintains gastrointestinal barrier function, leading to disruption in membrane phospholipids and subsequently decreased mucosal defense [20]. One of the postulated mechanisms for mucosal inflammation is that the byproduct, acyl gluconoride, causes local irritation of the epithelium which then stimulates mononuclear cells to release tumor necrosis factor (TNF)- $\alpha$, subsequently impacting the development of mucosal inflammation [20].

\section{Conclusions}

Since the advent of post-transplant immunosuppression therapy, MMF-induced enterocolitis is uncommon with debilitating complications; limited data is available in the literature regarding the approach to 
treatment. There continues to be unanswered questions as to why some patients' have refractory colitis, the benefits of oral or IV steroids, or biologic therapy (i.e. Infliximab), and the need for endoscopic reassessment for mucosal healing. With more cases being reported, we can better understand the natural course of the disease and help identify some of the answers. It is also prudent for physicians to inform the pathologist when a patient is on mycophenolate so the pathologist can be mindful of drug-induced colitis in the differential in addition to inflammatory bowel disease and GVHD.

\section{Additional Information \\ Disclosures}

Human subjects: Consent was obtained by all participants in this study. Conflicts of interest: In compliance with the ICMJE uniform disclosure form, all authors declare the following: Payment/services info: All authors have declared that no financial support was received from any organization for the submitted work. Financial relationships: All authors have declared that they have no financial relationships at present or within the previous three years with any organizations that might have an interest in the submitted work. Other relationships: All authors have declared that there are no other relationships or activities that could appear to have influenced the submitted work.

\section{References}

1. Allison AC, Eugui EM: Mycophenolate mofetil and its mechanisms of action . Immunopharmacology. 2000, 47:85-118. https://doi.org/10.1016/S0162-3109(00)00188-0

2. Lee FD: Importance of apoptosis in the histopathology of drug related lesions in the large intestine . J Clin Pathol. 1993, 46:118-122. http://dx.doi.org/10.1136/jcp.46.2.118

3. Dhakal P, Gami R, Giri S, Bhatt VR: Mycophenolate mofetil (MMF)-induced colitis. Blood. 2016, 128:4795. https://doi.org/10.1182/blood.V128.22.4795.4795

4. Behrend M: Adverse gastrointestinal effects of mycophenolate mofetil . Drug. 2001, 24:645-663.

5. Farooqi R, Kamal A, Thind K, Burke C: Mycophenolate-induced colitis. Am J Gastroenterol. 2018, 113:S889S890.

6. Calmet FH, Yarur AJ, Pukazhendhi G, Ahmad J, Bhamidimarri KR: Endoscopic and histological features of mycophenolate mofetil colitis in patients after solid organ transplantation. Ann Gastroenterol. 2015, 28:366-373.

7. Selbst MK, Ahrens WA, Robert ME, Friedman A, Proctor DD, Jain D: Spectrum of histologic changes in colonic biopsies in patients treated with mycophenolate mofetil. Mod Pathol. 2009, 22:737-743.

8. Parfitt JR, Jayakumar S, Driman DK: Mycophenolate mofetil-related gastrointestinal mucosal injury: variable injury patterns, including graft-versus-host disease-like changes. Am J Surg Pathol. 2008, 32:13671372.

9. Kim K, Gardner JM, Schwartz M, Tompson ML, Ro JY: Mycophenolate mofetil- related colitis: a case report . Korean J Pathol. 2010, 44:333-7. https://doi.org/10.4132/KoreanJPathol.2010.44.3.333

10. Goyal A, Salahuddin M, Govil Y: A unique case of mycophenolate induced colitis after 10 years of use . Case Rep Gastrointest Med. 2016, 1-3. http://dx.doi.org/10.1155/2016/3058407

11. Bouhbouh S, Rookmaaker MB: Rapid resolution of persistent mycophenolate mofetil-induced diarrhea with a single dose of infliximab. Nephrol Dial Transplant. 2010, 25:3437-8. https://oi.org/10.1093/ndt/gfq379

12. Johal K, Ratuapli SK, Lam-Himlin DM, Gurudu SR: Mycophenolate mofetil-induced segmental colitis mimicking ischemic colitis. Case Rep Gastroenterol. 2014, 8:95-100. https://doi.org/10.1159/000360847

13. Tayyem O, Saraireh H, Al-Hanayneh M, Stevenson HL: Heart transplant recipient with mycophenolate mofetil-induced colitis: the great imitator. BMJ Case Rep. 2018, https://doi.org/10.1136/bcr-2017-224035

14. Patra S, Vij M, Sukanya B, Kapoor D: Mycophenolate mofetil-induced colitis with graft versus host diseaselike features in a liver transplant recipient. Indian J Pathol Microbiol. 2012, 55:506-8. https://doi.org/10.4103/0377-4929.107792

15. Jakes AD, Roy A, Veerasamy M, Bhandari S: Case report: Crohn's-like mycophenolate-induced colitis, a fallout in steroid-free regimens. Transplant Proc. 2013, 45:842-44.

https://doi.org/10.1016/j.transproceed.2012.11.003

16. Moroncini G, Benfaremo D, Mandolesi A, Gabrielli A: Mycophenolate mofetil-induced colitis in a patient with systemic sclerosis. BMJ Case Rep. 2018, https://doi.org/10.1136/bcr-2018-224829

17. Gorospe EC: Chronic diarrhoea from mycophenolate mofetil-induced colitis . BMJ Case Rep. 2012, https://doi.org/10.1136/bcr.12.2011.5344

18. Sonoda A, Wada K, Mizukami K, et al.: Deep ulcers in the ileum associated with mycophenolate mofetil Intern Med. 2017, 56:2883-2886. https://doi.org/10.2169/internalmedicine.8815-17

19. Hamouda M, Mahmoudi H, Skhiri H, Elmay M.: Mycophenolate mofetil-related pancolitis in a kidney transplant recipient. Exp Clin Transplant. 2012, 10:501-05. https://doi.org/10.6002/ect.2011.0200

20. Davies NM, Grinyó J, Heading R, Maes B, Meier-Kriesche H, Oellerich M: Gastrointestinal side effects of mycophenolic acid in renal transplant patients: a reappraisal. Nephrol Dial Transplant. 2007, 22:2440-2448. https://doi.org/10.1093/ndt/gfm308 